\title{
Development of a high yield expression and purification system for Domain I of Beta-2-glycoprotein I for the treatment of APS
}

Thomas McDonnell ${ }^{*}$, Charis Pericleous ${ }^{1}$, Emmanuelle Laurine ${ }^{2}$, Rita Tommasi ${ }^{2}$, Acely Garza-Garcia ${ }^{3}$, lan Giles ${ }^{1}$, Yiannis loannou ${ }^{1,4}$ and Anisur Rahman ${ }^{1}$

\begin{abstract}
Background: In this paper we describe a novel method to achieve high yield bacterial expression of a small protein domain with considerable therapeutic potential; Domain I of Beta-2-glycoprotein I ( $\beta 2 \mathrm{GPI}$ ). $\beta 2 \mathrm{GPI}$ is intrinsic to the pathological progression of the Antiphospholipid Syndrome (APS). Patients develop autoantibodies targeting an epitope located on the N-terminal Domain I of $\beta 2 \mathrm{GPI}$ rendering this domain of interest as a possible therapeutic.
\end{abstract}

Results: This new method of production of Domain I of $\beta 2 \mathrm{GPI}$ has increased the production yield by $\sim 20$ fold compared to previous methods in E.coli. This largely scalable, partially automated method produces 50-75 mg of pure, folded, active Domain I of $\beta 2 \mathrm{GPI}$ per litre of expression media.

Conclusion: The application of this method may enable production of Domain I on sufficient scale to allow its use as a therapeutic.

Keywords: Antiphospholipid syndrome, Protein production, Inclusion bodies, E. Coli, Beta-2-Glycoprotein I, Domain I, Automated

\section{Background}

Protein-based biologic agents are increasingly used in the treatment of a range of autoimmune diseases. They may exert their effects by blocking receptor-ligand or antibody-antigen interactions or by delivering an exogenous enzyme such as uricase [1-5]. It is necessary however, to modify small proteins in order to create optimal therapeutic agents in particular to increase their in-vivo half-life and reduce their immunogenicity. PEGylation is one of the main methods used to achieve this and PEGylated proteins currently used in clinical practice include Puricase ${ }^{\bullet}$ (PEG-uricase) for gout $[2,6]$, PegIntron $\%$ PEGASYS $^{\circ}$ (PEG-Interferon alpha) for hepatitis $\mathrm{C}$ and myeloid leukemia $[7,8]$ and $\mathrm{Cimzia}^{\circ}$ (certolizumab pegol) for rheumatoid arthritis [9-11]. The production of pure active PEGylated protein requires significant amounts of native human protein as raw material for PEGylation and

\footnotetext{
*Correspondence: Thomas.mcdonnell.11@ucl.ac.uk

${ }^{1}$ Centre for Rheumatology, Division of Medicine, University College London, Rayne Institute, 5 University Street, London WC1E 6JF, UK

Full list of author information is available at the end of the article
}

extraction of these amounts from blood samples of human volunteers is not feasible. It is therefore critical to obtain large scale production of recombinant soluble, folded protein to be used as starting material for PEGylation. Mammalian, insect, yeast and bacterial expression systems could all be used to approach this goal.

The advantages of heterologous protein expression in Escherichia coli are many fold: (I) the technique is well studied and established, (II) yields per volume of culture are potentially very high, (III) the materials and carbon sources needed for cell growth and protein expression are inexpensive and, (IV) a variety of E coli-expressed proteins suitable for human use have already been commercialised [12-14]. There are, however, also significant drawbacks to bacterial expression. One of the most significant is that recombinant proteins are often misfolded and/or aggregated and found in insoluble particles called inclusion bodies. Refolding aggregated protein is a complex process resulting in low yields $[15,16]$. Another limitation of expression in the bacterial cytoplasm is the impossibility of obtaining proteins with post-translational 
modifications such as disulphide bond formation or glycosylation. In some cases, this limitation can be circumvented by directing the expression product to the bacterial periplasm where some post-translational modifications naturally occur. Also, advances have been made in the design of genetically engineered bacterial strains with enhanced post-translational modification capabilities [17-19]. The final consideration when proteins are produced in E. coli is contamination of the purified protein with Gram-negative bacterial cell wall components. The presence of these endotoxins precludes the use of the preparation in vivo or for cell culture studies.

Mammalian cell expression has some advantages over bacterial expression, mainly lack of endotoxin contamination and production of proteins with native or nearnative post-translational modifications. Yields tend to be lower than in bacterial expression, but methods have been developed to increase them [20], The main disadvantages of expression in mammalian cells are that it requires very specialised equipment $[20,21]$ is expensive -at least in a bench top scale-, and expression levels rely heavily on a random integration process [21]. Similarly some groups use insect cells and yeasts such as Pichia pastoris. However, these systems are less well-developed, can be delicate to manipulate, lower yields are frequent and yeast tends to generate escape mutants in culture [22]. It is for these reasons, cost, efficiency, flexibility and convenience, that most often laboratory protein expression prefers to utilize bacterial hosts.

In this paper we describe the development of a novel method for medium scale bacterial expression of a small protein domain with considerable therapeutic potential, the N-terminal domain of beta-2-glycoprotein I ( $\beta 2 \mathrm{GPI}$ ), commonly designated domain I (DI). DI is a critical antigen in the anti-phospholipid syndrome (APS).

APS is an autoimmune disease characterised by vascular thrombosis and/or recurrent miscarriages in patients and is a significant cause of mortality and morbidity. It is also the leading cause of strokes in patients under 50 years of age [23-25]. The disease is characterised by the presence of a heterogeneous population of auto-antibodies [26] that bind a range of antigens, in particular beta-2-glycoprotein I ( $\beta 2$ GPI) [25, 27-29]. Anti- $\beta 2$ GPI antibodies have been closely associated with thrombosis implying a significant role of these antibodies in the pathogenesis of the disease $[30,31]$. Current treatment for APS patients is long-term anticoagulation with warfarin or heparin, which are a non-specific vitamin $\mathrm{K}$ dependent coagulation blocking agent and an activator of anti-thrombin III respectively. These treatments lack efficacy in some cases and carry a significant risk of side-effects such as haemorrhage [32]. There is thus a pressing need to develop new targeted therapies such as drugs that would inhibit binding of anti$\beta 2 \mathrm{GPI}$ antibodies to $\beta 2 \mathrm{GPI}$. The critical pathogenic epitope of $\beta 2$ GPI $[25,29,33,34]$ has been defined as a conformational epitope covering residues 8 and 9 and 39-43 on DI. Recombinant DI inhibits the binding of antibodies derived from APS patients to $\beta 2$ GPI in ELISA binding assay [25]. In vivo studies showed that recombinant DI inhibits the development of thrombosis in mice exposed to IgG from patients with APS [23]. DI is non-glycosylated and is thus ideally suited for bacterial expression. We have also used recombinant DI as the substrate in an ELISA to detect serum anti-DI antibodies. In studies of large numbers of sera from patients with APS, autoimmune disease controls and healthy controls, anti-DI positivity enhances the ability to differentiate patients with APS from other groups (reviewed in Bertolaccini et al. [35]).

In previously published work we developed two methods for the expression of DI in E. coli. The yield of soluble hexa-histidine tagged DI was around $0.75 \mathrm{mg} / \mathrm{L}$ of bacterial culture [36] when the expression product was targeted to the bacterial periplasm and approximately $4 \mathrm{mg} / \mathrm{L}$ when recovered from inclusion bodies [37]. Now we present a novel method suitable for medium-scale production of highly pure human DI in E.coli, and verify protein activity by ELISA assays showing that the expression product inhibits binding of IgG from patients with APS to $\beta 2 \mathrm{GPI}$.

\section{Methods}

All chemicals were purchased from Sigma, unless otherwise stated.

\section{DI expression vector}

The synthetic DI coding sequence as previously published [37] was cloned into an in-house modified vector that incorporates an N-terminal fusion tag consisting of an hexa-histidine motif for purification and expression, a BirA biotinylation site and a Factor Xa recognition sequence for proteolytic cleavage (Fig. 1). These modifications were introduced into pETHis_1a (a kind gift from Gunter Stier, then at EMBL Heidelberg), which is itself a modified pET24d vector (Merck Millipore). The biotinylation site was introduced during the development of the vector to allow the option of binding to streptavidin-coated plates in ELISA, but we are not using biotinylated DI for any purpose at present.

\section{Small scale protein expression test in Luria Broth (LB) and Terrific Broth (TB)}

Transformation of $\mathrm{BL} 21^{*} \mathrm{DE} 3^{\circ}$ (Life Technologies) cells was carried out according to the manufacturer's instructions. Cells were plated into LB/agar with kanamycin $50 \mu \mathrm{g} / \mathrm{ml}$. Single colonies were picked and subcultured into $3 \mathrm{ml}$ of LB media containing kanamycin $(50 \mu \mathrm{g} / \mathrm{ml})$ and incubated overnight at $250 \mathrm{rpm}$ and $37^{\circ} \mathrm{C} .150 \mu \mathrm{l}$ of 


\section{Sequence Insert Encoding DI and Tag.}
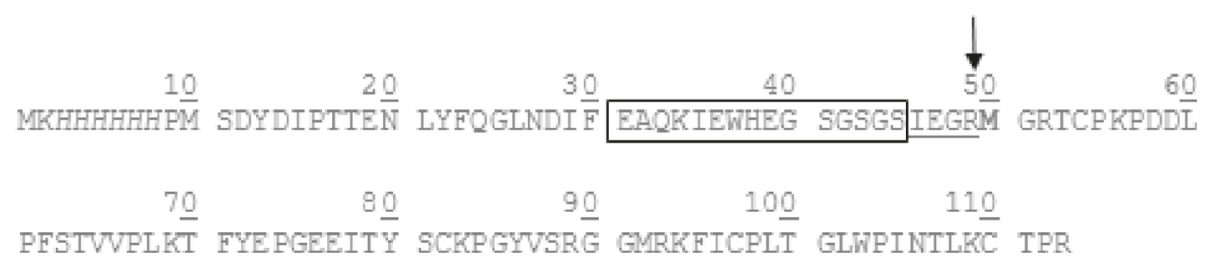

Fig. 1 DI fusion protein sequence showing the N-terminal hexa-histidine tag (italics), the BirA recognition site for potential biotinylation (boxed) and the restriction protease FXa cleavage site (underlined). The cleavage site is indicated with an arrow and the first amino acid of DI is bolded. The fusion protein is $12.9 \mathrm{kDa}$ while native DI which contains 64 amino acids is $7.2 \mathrm{kDa}$

preculture were used to inoculate $3 \mathrm{ml}$ of $\mathrm{LB}$ or TB and cells were incubated at $250 \mathrm{rpm}$ and $37{ }^{\circ} \mathrm{C}$; growth was monitored by OD at $600 \mathrm{~nm}$. For cultures in LB, expression was induced with $1 \mathrm{mM}$ IPTG at an $\mathrm{OD}_{600 \mathrm{~nm}}$ of 0.6 . In order to compare different expression temperatures, the induced culture was incubated overnight with shaking at $250 \mathrm{rpm}$ at either $20{ }^{\circ} \mathrm{C}$ or $37{ }^{\circ} \mathrm{C}$. For cultures in TB, expression was induced with $1 \mathrm{mM}$ IPTG at an $\mathrm{OD}_{600 \mathrm{~nm}}$ of between 5 and 7. Post induction, expression was continued overnight with shaking at $250 \mathrm{rpm}$ at $20{ }^{\circ} \mathrm{C}$. Cells were harvested by centrifugation for $20 \mathrm{~min}$ at $20,000 \mathrm{xg}$ and $4{ }^{\circ} \mathrm{C}$. Pellets were lysed in $500 \mu \mathrm{l}$ of $1 \%$ Triton $\mathrm{x}-100$ and $1 \mathrm{x}$ PBS, by three cycles of sonication (output 100, $3 \mathrm{~min}$ ). Samples were analysed by SDS PAGE.

\section{Large scale protein expression in TB}

A glycerol stock was used to inoculate $200 \mathrm{ml}$ of LB. Cultures were incubated overnight with shaking at $225 \mathrm{rpm}$ and $37{ }^{\circ} \mathrm{C}$, centrifuged at $3500 \times$ g for $30 \mathrm{~min}$ at room temperature and resuspended in $20 \mathrm{ml}$ of fresh LB. Two litres of TB were seeded in four 2 L-flasks with $5 \mathrm{ml}$ of pre-culture in each. Expression was then carried out as for the small scale protocol.

\section{Harvesting}

Harvesting was carried out using a $500 \mathrm{kDa}$ Hollow Fiber Ultrafiltration Cartridge (GE Healthcare). The cell suspension was run into the cartridge at $100 \mathrm{rpm}$ until a pellet was formed and the bacterial pellet was further rinsed by addition of $2 \mathrm{~L}$ of PBS. The pellet was transferred into $50 \mathrm{ml}$ centrifuge tubes, spun at 3,500 $\times \mathrm{g}$ for $30 \mathrm{~min}$ to remove any remaining PBS and finally snap frozen using dry ice.

\section{Cell lysis and inclusion body solubilisation}

Lysis Buffer (A; $50 \mathrm{mM}$ sodium phosphate, 0.3 M Sodium Chloride, $10 \mathrm{mM}$ Imidazole) was added to the frozen pellet with the addition of DNase $(0.02 \mathrm{mg} / \mathrm{ml})$ and protease inhibitors (1:500). Bacterial pellets were suspended by vortexing and pipette mixing. The lysate was then sonicated (50\% maximum intensity, $50 \%$ cycles) for $4 \mathrm{~min}$, allowed to cool for $2 \mathrm{~min}$. This was repeated once. The inclusion bodies were collected by centrifugation of the lysate at $3,500 \times \mathrm{g}$ for $30 \mathrm{~min}$. Lighter inclusion bodies were harvested by spinning the supernatant once again at 20,000 $\times$ g for $30 \mathrm{~min}$.

\section{Inclusion body preparation}

The inclusion bodies were resuspended in Solubilisation Buffer (B; $6 \mathrm{M}$ guanidine hydrochloride, $0.1 \mathrm{M} \mathrm{NaH}_{2} \mathrm{PO}_{4}$, $10 \mathrm{mM}$ Tris, $\mathrm{pH}$ 8.0) initially by grinding in a pestle and mortar homogeniser. The suspension was sonicated twice for $4 \mathrm{~min}$ (50\% maximum intensity, $50 \%$ cycles), in order to promote protein solubilisation and reduce viscosity. The suspension was finally centrifuged at $20,000 \times \mathrm{g}$ for $20 \mathrm{~min}$ to remove insoluble debris prior to purification.

\section{Purification of denatured protein by immobilised metal affinity chromatography (IMAC)}

The solubilised protein was loaded at $2-5 \mathrm{ml} / \mathrm{min}$ onto a 15-ml HisTrap FF (GE Healthcare) and washed with 1.5 column volumes $(\mathrm{CV})$ of Denaturing IMAC Equilibration Buffer ( $\mathrm{C}$; $6 \mathrm{M}$ guanidine hydrochloride, $0.1 \mathrm{M} \mathrm{NaH}_{2} \mathrm{PO}_{4}, 10 \mathrm{mM}$ Tris, $\mathrm{pH}$ 6.3). The protein was eluted at $1 \mathrm{ml} / \mathrm{min}$ with $2.7 \mathrm{CV}$ of Denaturing IMAC Elution Buffer (D; $6 \mathrm{M}$ guanidine hydrochloride, $0.1 \mathrm{M} \mathrm{NaH}_{2} \mathrm{PO}_{4}, 10 \mathrm{mM}$ Tris, $\mathrm{pH}$ 4.5). The fractions were collected and analysed by SDS-PAGE. The entire purification process was conducted on an AKTA platform (GE Healthcare).

\section{In vitro oxidative protein folding}

The protein was pooled and concentrated to $25-30 \mathrm{mg} /$ $\mathrm{ml}$ by centrifugal concentrators. Any potential disulphide bonds were reduced by incubating overnight with $50 \mathrm{mM}$ TCEP at $4{ }^{\circ} \mathrm{C}$. TCEP was subsequently removed by buffer exchange using a PD-10 desalting column (GE Healthcare). The protein was recovered at a concentration of $>10 \mathrm{mg} / \mathrm{ml}$ and was loaded into a $5 \mathrm{ml}$ syringe. This syringe was fitted into a pump with the tip placed 
inside $95 \mathrm{~mL}$ of the Folding Buffer (E; 0.6 M arginine hydrochloride, $0.1 \mathrm{M}$ Tris, $\mathrm{pH}$ 8.5, $1 \mathrm{~mL}$ cysteine $(0.3 \mathrm{M})+1 \mathrm{~mL}$ cystine $(0.03 \mathrm{M})$. The pump was set to inject constantly at $300 \mu \mathrm{l} / \mathrm{h}$ and left overnight at $4{ }^{\circ} \mathrm{C}$. The resulting solution was centrifuged at $3,500 \times \mathrm{g}$ for $30 \mathrm{~min}$ at $4{ }^{\circ} \mathrm{C}$ and syringe filtered $(25 \mu \mathrm{m}$, Sartorius). The protein solution was further concentrated to approximately $3-5 \mathrm{mg} / \mathrm{ml}$ by Vivaspin ${ }^{\circ}$ centrifugal ultrafiltration (5 kDa MWCO, Satorius) and dialysed for $2 \mathrm{~h}$ (3.5 KDa MWCO;, snake skin, thermo scientific) against $5 \mathrm{~L}$ of Native IMAC Equilibration Buffer (F; $20 \mathrm{mM}$ Tris, $0.1 \mathrm{M} \mathrm{NaCl}, \mathrm{pH}$ 8.0) at $4{ }^{\circ} \mathrm{C}$. Dialysis buffer was changed after $2 \mathrm{~h}$ and the protein was further dialysed overnight at $4{ }^{\circ} \mathrm{C}$. The resultant protein was collected and used for purification by IMAC.

\section{Isolation of folded and monomeric protein by IMAC in native conditions}

Dialysed protein was purified using a 15-ml HisTrap FF (GE Healthcare) at a flow rate of $2 \mathrm{ml} / \mathrm{min}$. The flowthrough was collected and the column washed with 3-4 $\mathrm{CV}$ of Buffer $\mathrm{F}$. The protein was eluted with a gradient 0-100\% Native IMAC Elution Buffer (G; $20 \mathrm{mM}$ Tris, $0.1 \mathrm{M} \mathrm{NaCl}, 1 \mathrm{M}$ imidazole, pH 8.0) over $8 \mathrm{CV}(2 \mathrm{ml} /$ $\mathrm{min})$. Five millilitre fractions were collected and analysed by SDS PAGE. The fractions containing recombinant his-tagged DI were pooled and stored at $4{ }^{\circ} \mathrm{C}$.

Fusion tag cleavage and purification of untagged protein Purified recombinant tagged DI was dialysed against PBS $\left(\sim 30 \mathrm{ml}\right.$ in $2 \mathrm{~L}$ of PBS for $2 \mathrm{~h}$ at $4{ }^{\circ} \mathrm{C}$ then the buffer was exchanged for $2 \mathrm{~L}$ of fresh PBS) and freezedried over $48 \mathrm{~h}$ in 1 or $2 \mathrm{mg}$ aliquots. Lyophilised recombinant tagged DI was re-suspended in Cleavage Buffer $(\mathrm{H} ; 50 \mathrm{mM}$ Tris, $0.1 \mathrm{M} \mathrm{NaCl}, 1 \mathrm{mM} \mathrm{CaCl}$, $\mathrm{pH}$ 6.5) and human FXa (Haematologic Technologies) was added at a ratio of 1:200 to protein (i.e. $1 \mu \mathrm{g}$ enzyme per $200 \mu \mathrm{g}$ protein), protein concentration was kept below $1 \mathrm{mg} / \mathrm{ml}$ to avoid aggregation. Calcium chloride was added to a final concentration of $2 \mathrm{mM}$ and the mixture was incubated without shaking for $\sim 16 \mathrm{~h}$ at $22{ }^{\circ} \mathrm{C}$. Samples were analysed by SDS-PAGE to assess the completion of cleavage.

The cleaved protein was loaded onto a $5 \mathrm{ml}$ HiTrap SP HP column (GE Healthcare) pre-equilibrated with 3-5 CV of IEX Equilibration Buffer (I; 20 mM HEPES, $\mathrm{pH}$ 6.8). After sample loading the column was further washed with $3 \mathrm{CV}$ of Buffer I and the sample was eluted with a 0-100 \% linear gradient of IEX Elution Buffer (J: 20 mM HEPES, 1 M sodium chloride, $\mathrm{pH}$ 6.8). Fractions were collected, analysed by SDS-PAGE and relevant fractions were pooled, dialysed against $\mathrm{PBS}$ at $4{ }^{\circ} \mathrm{C}$ ( $2 \mathrm{~L}$ for $2 \mathrm{~h}, 1$ change, and $2 \mathrm{~L}$ for $16 \mathrm{~h}$ ), aliquoted and freeze dried prior to storage at $-80^{\circ}$.

\section{Reverse phase HPLC}

Both VariTide RPC (Agilent) and Poroshell C8 (Agilent) columns were used for RP-HLPC. Ten- $\mu$ g samples dissolved in solvent $\mathrm{A}$ were injected and run across either a 4 or a 10 min gradient of $0-100 \%$ solvent B. Solvent A was $2 \%$ acetonitrile and $0.065 \%$ TFA in $\mathrm{ddH}_{2} \mathrm{O}$ and solvent B was $100 \%$ acetonitrile and $0.05 \%$ TFA. Spectra were analysed using Chromeleon ${ }^{\circ}$ software (Dionex).

\section{Endotoxin removal and quantification}

EndoTrap ${ }^{\circ}$ high capacity columns (Hyglos) were used for endotoxin removal following the manufacturer's instructions with the following adaptations: protein was dialysed against PBS overnight before being dialysed into endotoxin-free PBS via centrifugal ultrafiltration. The buffer was supplemented with $1 \mathrm{mM}$ calcium chloride.

The EndoLISA ${ }^{\circ}$ fluorescence assay (Hyglos) was used for endotoxin quantification following the instructions of the manufacturer. The amount of endotoxin was quantified in protein samples at concentrations between $0.1 \mathrm{mg} / \mathrm{ml}$ and $2 \mathrm{mg} / \mathrm{ml}$.

\section{Competitive inhibition ELISA}

Competitive inhibition ELISA was carried out to test the ability of recombinant DI to inhibit binding of purified IgG from patients with APS to immobilised $\beta 2$ GPI. The assay was adapted from the standard $\beta 2$ GPI ELISA published by Ioannou et al. [36] with the following amendments: the inhibitors were pre-incubated at concentrations ranging from $0 \mathrm{mg} / \mathrm{ml}$ to $200 \mu \mathrm{g} / \mathrm{ml}$ rather than 0 to $30 \mu \mathrm{M}$. Briefly, the test was carried out to test the ability of recombinant DI to inhibit binding of purified IgG from patients with APS to $\beta 2$ GPI coated on a plate. Recombinant DI was pre-incubated with patient serum prior to addition on the ELISA plate coated with $\beta 2$ GPI. Bound patient IgG was detected with an anti-human IgG HRP secondary antibody. Each sample was tested in duplicate.

Ethical approval for use of samples from patients in this research was granted by the London Hampstead Research Ethics Committee Reference Number 12/LO/ 0373. Patients gave informed consent for use of their samples.

\section{Results and discussion}

\section{DI fusion protein expression}

DI was expressed as a fusion protein containing an additional $\mathrm{N}$-terminal tag including a hexahistidine tag for purification, a biotinylation site and a FXa cleavage motif (Fig. 1). A FXa recognition site was chosen over other more common proteases because no extra amino acids remain in the recombinant protein after cleavage.

In order to optimise the conditions for the protein expression preliminary small scale expression tests were performed in 24-well plate format. The following conditions 
A

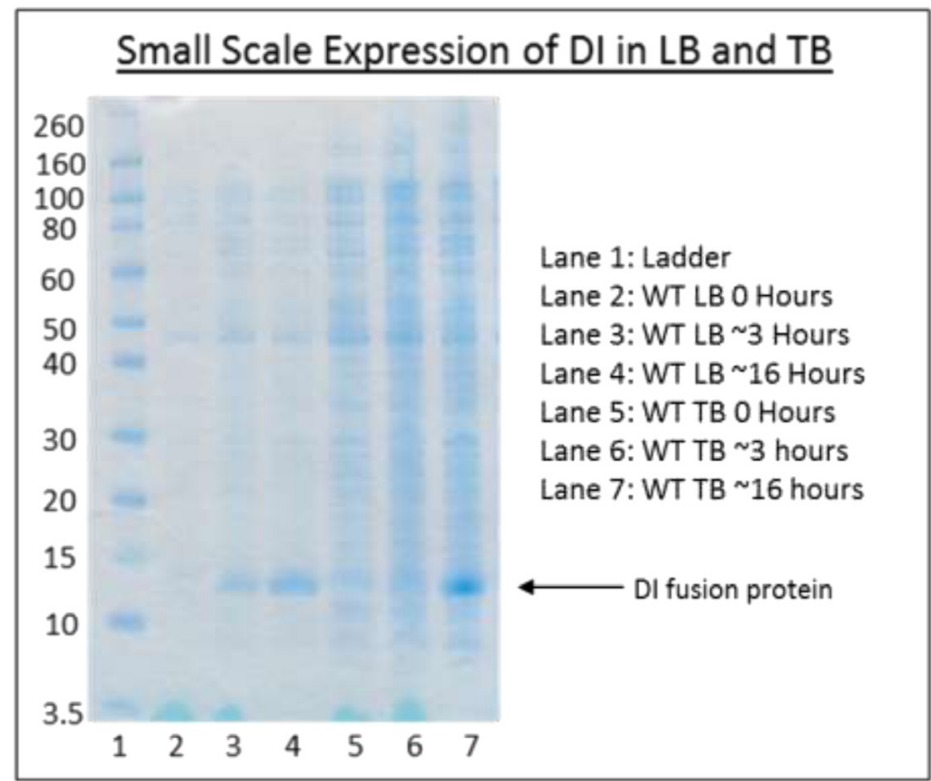

B

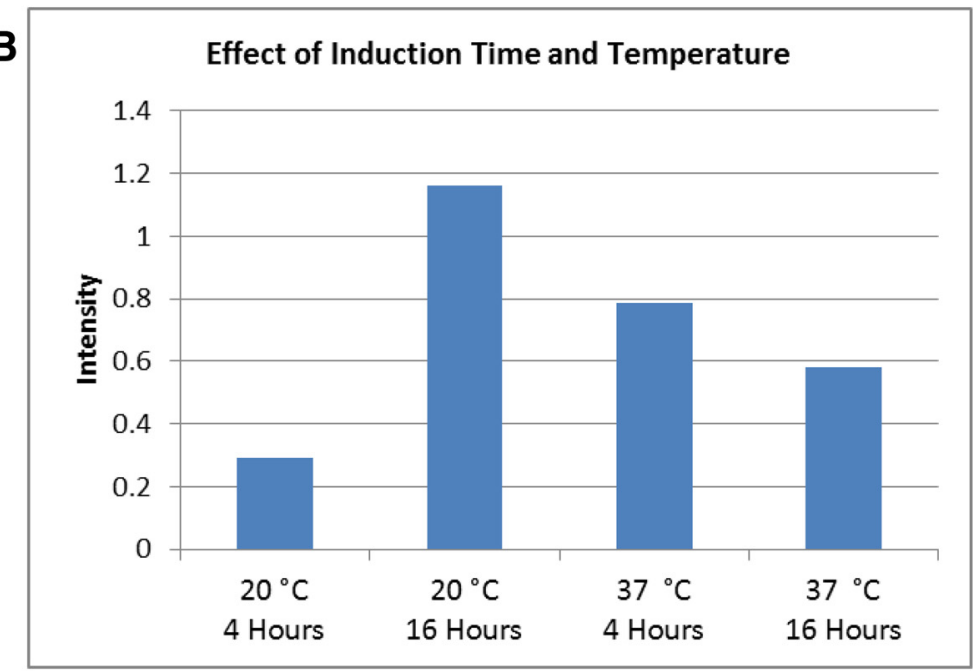

C

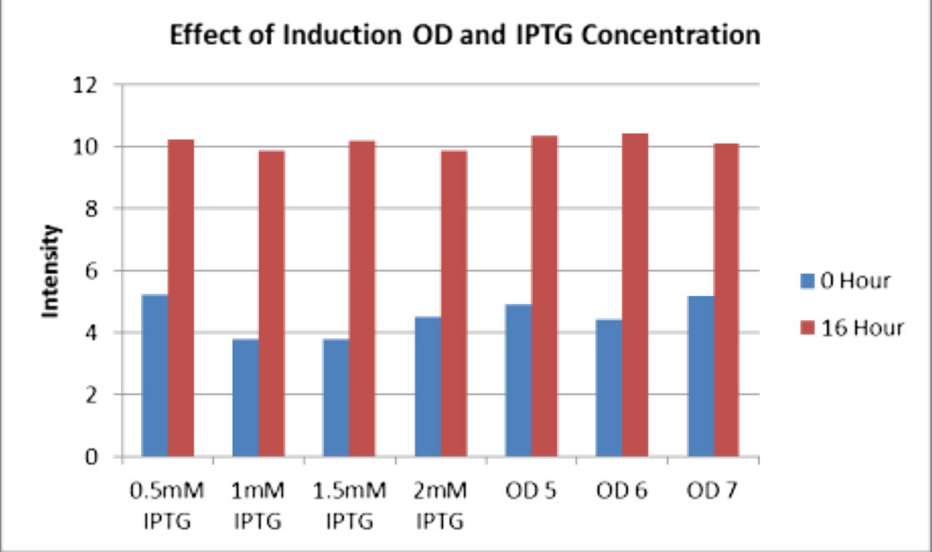

Fig. 2 (See legend on next page.) 
(See figure on previous page.)

Fig. 2 a SDS-PAGE gel comparing crude lysates of small scale expression of tagged Domain I fusion protein in LB and TB media before and after induction. Recombinant tagged DI fusion is indicated by an arrow and migrates at $12 \mathrm{kDa}$. Samples were lysed using triton/PBS and diluted in PBS (5x) and $20 \mu \mathrm{l}$ was loaded onto an SDS PAGE Gel. The gel was then run, washed briefly in ddH2O and stained for $1 \mathrm{~h}$ with InstantBlue ${ }^{\mathrm{TM}}$ stain (Expedeon, UK). b \& c Densitometric analysis was carried out on LB and TB samples on a small scale loaded in an identical way, gels were scanned, images converted to TIFF files and analysed. Values represent a calculation of intensity divided by area, OD denotes optical density of cultures at $600 \mathrm{~nm}$ at induction

were tested: Type of medium (LB or TB), IPTG concentration $(0.5 \mathrm{mM}, 1 \mathrm{mM}$ or $2 \mathrm{mM})$, length of incubation after induction ( 8 or $16 \mathrm{~h}$ ) and temperature of incubation after induction $\left(20{ }^{\circ} \mathrm{C}\right.$ or $\left.37{ }^{\circ} \mathrm{C}\right)$. At the end of the incubation, bacteria were pelleted, lysed and the crude extract was analysed by SDS-PAGE in order to assess the level of protein expression (Fig. 2). Growth in $\mathrm{TB}$ with induction at an $\mathrm{OD}_{600}$ between 5 and 7 with $1 \mathrm{mM}$ IPTG for $16 \mathrm{~h} 20{ }^{\circ} \mathrm{C}$ was selected as the best condition for the expression of DI fusion protein (Fig. 2); IPTG at $0.5 \mathrm{mM}$ could also be used in the future for larger scale production, as within the tested range, the concentration of IPTG had no impact on the level of expression. No changes in expression level were observed when the production was scaled up to 21 . Using precultures with an $\mathrm{OD}_{600 \mathrm{~nm}}$ between 0.1

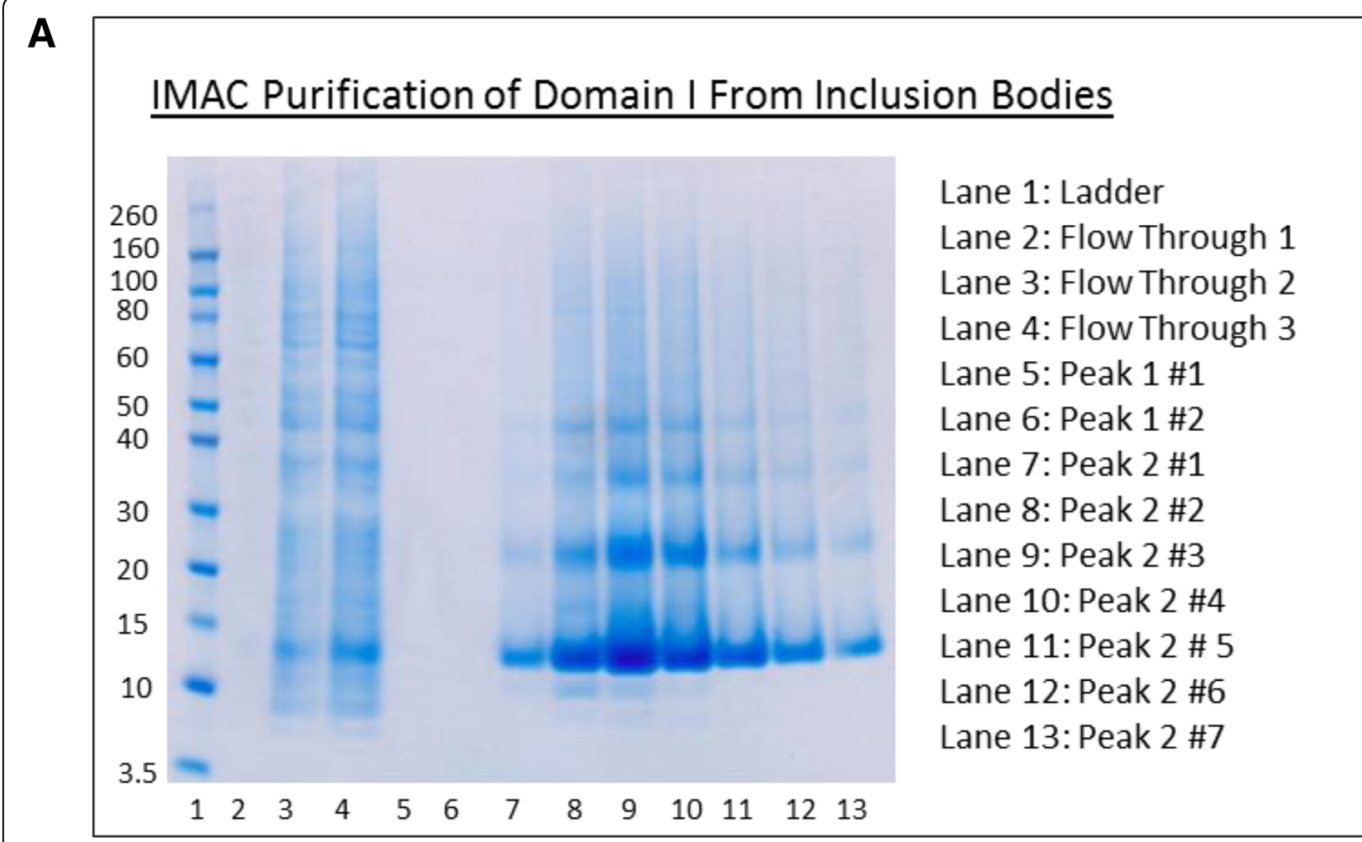

B

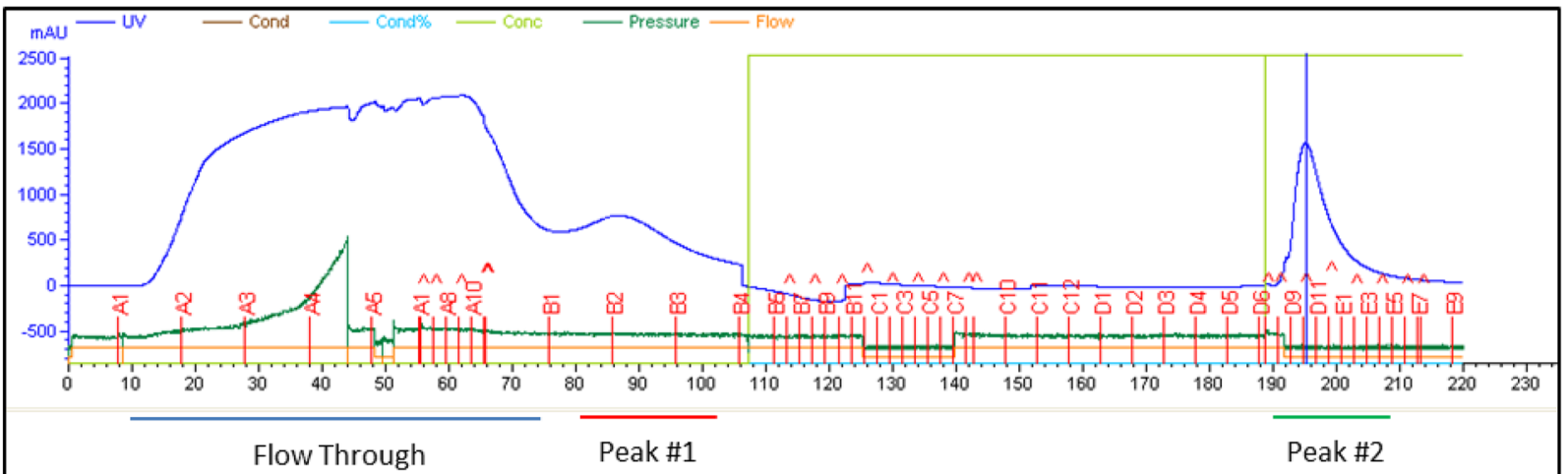

Fig. 3 a Analysis of denaturing IMAC elution fractions by SDS-PAGE. Samples were diluted 1:8 in water and $15 \mu$ l of each dilution were loaded per well. b An accompanying chromatogram with two peaks highlighted at the bottom. Peak \#1 shows no protein on the gel (lanes 5 and 6 ) as the amount of this protein was insignificant after dilution to remove guanidine 
and 0.2 , the expression would reach induction density $\left(\mathrm{OD}_{600 \mathrm{~nm}} 5-7\right)$ within $5 \mathrm{~h}$ and reach an overnight $\mathrm{OD}_{600}$ of approximately $10-13$. Bacteria were harvested by either centrifugation or hollow fiber ultrafiltration. For convenience and suitability for scaling up, ultrafiltration was selected for large scale productions. Typical expression yields were in the order of $20 \mathrm{~g}$ of wet cell pellet per litre of culture.

\section{DI in vitro folding and purification \\ Cell lysis and inclusion body solubilisation}

Bacterial pellets were lysed as described in the Methods. Briefly, the bacterial pellets were resuspended in Lysis buffer and subjected to two cycles of sonication. Optimal lysis of the bacterial pellet was achieved using 80 to $100 \mathrm{~mL}$ of Buffer A per $40 \mathrm{~g}$ of wet cell pellet. Addition of DNase and protease inhibitors in the lysis buffer led to a marked decrease in viscosity of the lysate and an increase in solubility of inclusion bodies at the solubilisation step. The inclusion bodies were collected by centrifugation, re-suspended in Buffer $\mathrm{B}$ and homogenised by a combination of grinding with a pestle and mortar, sonicating and pipette mixing; sonication was essential for solubilisation of the inclusion bodies containing DI fusion protein while the incubation temperature had no impact on the solubilisation efficiency. Although using more Buffer B had no impact on the solubilisation yield, less concentrated preparations were less viscous, facilitating subsequent procedures.

\section{Purification of denatured DI by IMAC}

Solubilised protein from the inclusion bodies was purified by IMAC. DI fusion protein was eluted with a gradient of $\mathrm{pH}$ and elution fractions were analysed by SDS-PAGE (Fig. 3). The flow-through still contained a limited amount of DI fusion protein (Lanes 2-4). Elution fractions showed a high concentration of DI fusion protein at $\sim 12 \mathrm{kDa}$ as well as dimers $(\sim 24 \mathrm{kDa})$ and multimers. In addition, a smaller species $(\sim 10 \mathrm{kDa})$ was observed in the highly concentrated fractions (lanes 8-9) and could correspond to a truncated or a degraded fragment of the fusion protein containing the $\mathrm{N}$-terminal fusion tag.

Automated and gravity-driven drop columns were both used and the automated method was preferred due to scale of the purification. As expected an excess of protein to the column resulted in preparations of higher purity, as non-specific binding occurs when the resin binding sites are not fully occupied. Introducing a washing step using Buffer $C$, greatly reduced the amount of impurities. Although impurities appear faint on SDS PAGE gels, their absorption at $280 \mathrm{~nm}$ was sufficient to be seen on a chromatograph. After this first step of purification, the yield of purified denatured DI fusion protein was around 125-150 mg of protein/ l of medium when quantified in guanidine.

\section{In vitro folding of DI fusion protein and IMAC purification} in native conditions

Two methods were compared for the in vitro folding of DI fusion protein. The first method was stepwise addition of $\sim 1.0 \mathrm{mg}$ (at a concentration of $>10 \mathrm{mg} / \mathrm{ml}$ ) of denatured protein into $100 \mathrm{ml}$ of Buffer $\mathrm{E}$ while stirring at $4{ }^{\circ} \mathrm{C}$; a total of 4 or 520 - $\mu$ l additions were made. The second method was continuous automated addition of protein using a syringe pump injecting the DI fusion protein (at a concentration $>10 \mathrm{mg} / \mathrm{mL}$ ) in the refolding buffer with a speed of $300 \mu \mathrm{L} / \mathrm{h}$. The automated continuous addition method resulted in less protein aggregation after overnight incubation. The maximum yield of soluble protein obtained by continuous addition was $150 \mathrm{mg}$ in $100 \mathrm{ml}$ of Buffer E. Denatured protein concentration during folding was critical for the final yield of soluble protein, protein folded at concentrations lower than $10 \mathrm{mg} / \mathrm{mL}$ aggregated overnight.

The soluble DI fusion protein was then concentrated and dialysed against Buffer F prior to IMAC-purification in non-denaturing conditions. Avoiding high protein concentrations at this stage was critical and a concentration for folded fusion protein of 2 to 2.5 fold was found to be optimal. IMAC purification at this stage was very successful for the removal of impurities (Fig. 3, $10 \mathrm{kDa}$ band), misfolded species and aggregates. Yield after IMAC purification was between 50 and $75 \mathrm{mg}$ per litre of expression medium.

A Demonstration of Cleavage of Fusion Tag From DI Using FXa

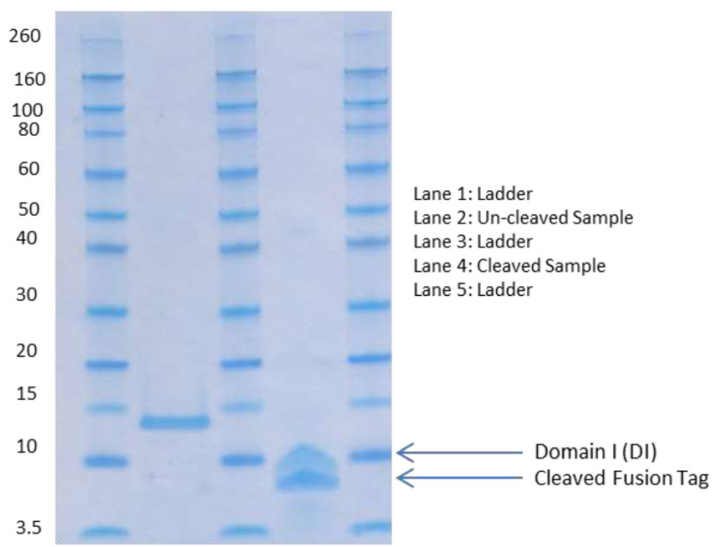

Fig. 4 An SDS PAGE gel depicting purified DI fusion protein before FXa cleavage (Lane 2) and native DI and released fusion tag after FXa cleavage (labelled accordingly) 
Fusion tag cleavage, purification of untagged DI and endotoxin removal

Removal of the N-terminal tag was performed by addition of restriction protease $\mathrm{FXa}$ to the fusion protein at a ratio of 1:200 and incubation overnight at $22{ }^{\circ} \mathrm{C}$. The digested sample was then analysed by SDS-PAGE to confirm the completion of the digestion (Fig. 4). After overnight digestion the cleavage of the fusion protein was complete and SDS-PAGE analysis showed 2 bands (Fig. 4, lane 2), corresponding to the native DI $(\sim 8 \mathrm{kDa})$ and the fusion tag $(\sim 6 \mathrm{kDa})$. A final step of purification by cation exchange was performed and yielded $>99 \%$ pure monomeric DI as judged by SDS-PAGE (Fig. 5c) and reverse phase chromatography (Fig. 5a).
The concentration of protein for endotoxin removal was $0.3-0.6 \mathrm{mg} / \mathrm{mL}$ and required the addition of $1 \mathrm{mM}$ extra $\mathrm{CaCl}_{2}$ for optimal yield. Endotoxin removal was successful down to a level of $<1 \mathrm{EU} / 100 \mu \mathrm{g}$.

\section{DI protein characterisation by mass spectroscopy and an} activity assay

DI was characterised by molecular weight determination using MALDI-TOF mass spectroscopy. The mass spectrum of the full-length protein displayed an $\mathrm{m} / \mathrm{z}$ value of 7183.39 which is in agreement with the expected $\mathrm{m} / \mathrm{z}$ for the $[M+H]+$ species of 7187.59 , the mass error observed is within the calibration limitation given the small molecular weight of the protein.

\section{Characterisation, Identification and Purity Assessment of Expressed DI}
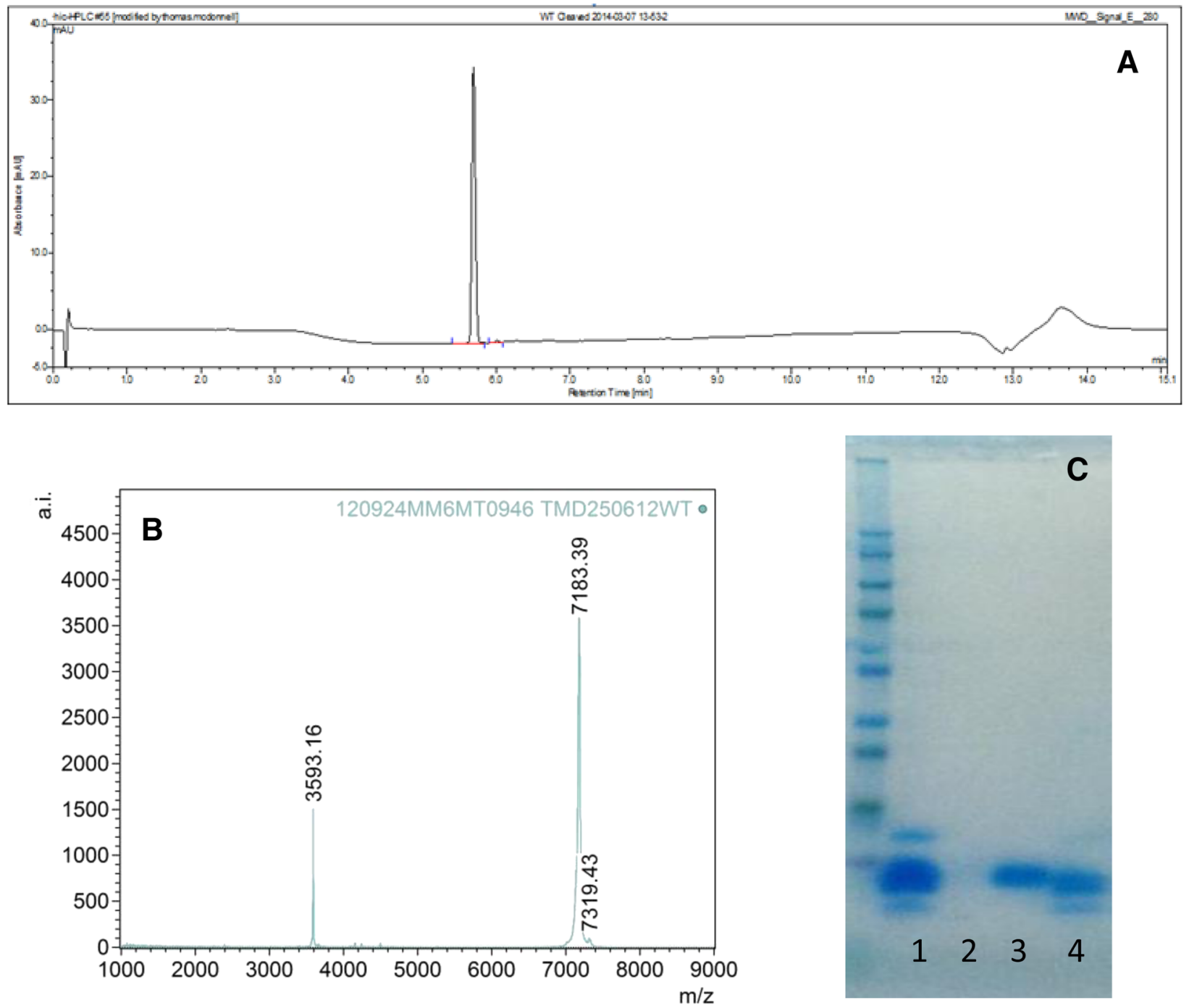

Fig. 5 Characterisation of various DI batches by (a) RP-HPLC (C8) analysis, (b) MALDI-TOF and (c) SDS-PAGE Lane (1) Fusion protein, Lane (3) purified $\mathrm{DI}$ and Lane (4) cleaved fusion Tag. Lane 2 is blank 
For the competitive inhibition ELISA, Serum samples were obtained from six patients with APS. Three were male, all were Caucasian and the mean (SD 13.9) age was 47. All six patients had suffered vascular thrombosis and two patients had suffered foetal losses $(1 \times 2,1 \times 3)$. Importantly, serum from all six patients had been found to have very high binding to $\beta 2 \mathrm{GPI}$ in a solid phase ELISA assay. Figure 6 shows that of six serum samples 4 were inhibited by $50 \%$ or more and two by $90 \%$ (at $175 \mu \mathrm{g} / \mathrm{ml}$ patient 1-6: 73.3, 12.5, 11.3, $49.8,13.4,58.3 \%)$.

\section{Conclusions}

Although other methodologies such as mammalian or yeast expression may offer other benefits, such as posttranslational modification or secretion of soluble product post-expression into medium, E.Coli offers many advantages to the lab scale scientist. It allows simple optimisation, is flexible, robust and can be translated to a GMP environment.

In this paper we present a protocol for the preparation of biologically active endotoxin-free DI expressed as inclusion bodies in E. coli. Denatured DI was purified by IMAC in guanidine hydrochloride, reduced with TCEP, and folded in vitro by dilution into a buffer containing $0.6 \mathrm{M}$ arginine as aggregation inhibitor and cysteine/ cysteine to promote the rearrangement of disulphide bonds. After further purification and fusion tag removal, the maximal yield was $50-75 \mathrm{mg}$ per $\mathrm{L}$ of expression media. This represents a 20 -fold increase on previous E. coli expression protocols for DI using in vivo folding by periplasmic localisation $(750 \mu \mathrm{g} / \mathrm{L}$ [36]) or in vitro folding ( 4 mg/L [37]).

The most vital stages of production, resulting in an increased yield, were the bacterial pellet collection, folding by continual injection and general automation. Replacing LB with TB resulted in an increase in yield but primarily due to an increased cell density rather than expression itself. This increased cell density led to a thicker lysate with more DNA, however, addition of DNAses to the lysate and extensive washing of the bacterial pellet reduced the viscosity and allowed a better purification process. These washes also reduced endotoxin levels during the purification process and resulted in a higher purity product. The instigation of automated refolding via the syringe pump increased yields by almost double and, when this was combined with a slower and less harsh dialysis protocol, optimal yields were obtained. It is generally accepted that aggregation occurs only between partially folded species and that the presence of folded protein does not result in increased aggregation [38], therefore gradual and very slow addition of protein to folding buffer reduces the effective concentration of unfolded species at any given moment. Similarly, the same can be said of the dialysis method. Automation of protein dilution also increased yields minimising the number of handling steps and human error. Interestingly, minimisation of the total protein concentration during the dialysis steps after folding also contributed to increase final protein yield, perhaps because a fraction of the protein is still partially unfolded at this stage.

Suggested future alterations to the method would include the introduction of an auto inducing culture [39]. Auto induction is a complex process but with the correct optimisation it may be used to increase the automation of the method, however, insufficient optimisation risks a decrease in yield. Despite the positive benefits of the new system we have described-increased expression, efficient folding and high purity- the method does have potential limitations. Preliminary attempts to use oncolumn refolding failed as the protein fell out of solution and stripped the column suggesting that alternative methods of folding may not be suitable during scale-up. On the other hand, only two methods of oncolumn refolding were tried and both utilised a $5 \mathrm{~mL}$ HisTrap IMAC column and further investigation with

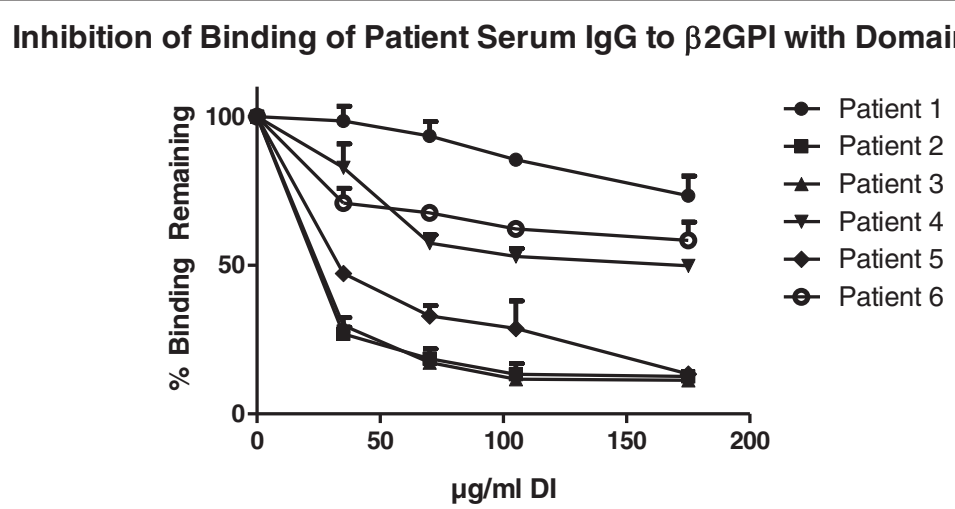

Fig. 6 Competitive Inhibition assay. Sera from six patients were tested using the purified Domain I at various concentrations. Values plotted are an average of 2 experiments, SEM plotted above each point 
other chemistries may improve the technique. The major limiting factor of the method is the large volume of buffer required for folding. Similarly, the manual process of grinding the cells is a drawback which could easily be improved with equipment such as a French press. It is therefore possible that further optimisation may improve protein yield even more.

Further improvements to this methodology are necessary for scaling up and automation. The major limitation at this stage is the need to concentrate protein solutions in several points during the process. The introduction of an on-column protein folding method would ameliorate this drawback. Unfortunately, our preliminary attempts to implement such a methodology in the case of DI have failed; presumably because of the very poor intrinsic protein solubility of unfolded DI, which resulted in rapid protein aggregation as soon as the concentration of guanidine was reduced. An alternative and more promising approach would be to substitute protein concentration by centrifugal ultracentrifugation by ion exchange chromatography or tangential flow filtration steps. Another change in the process required for scaling up is the replacement of cell lysis by sonication for high pressure disruption or by chemical methods. It is also possible that yields can also be increased by optimising and/ or altering the composition of the folding buffer, as a great variety of potential aggregation inhibitors has been described in the literature [38].

Regarding the activity of the protein, the inter patient variability in susceptibility to inhibition by DI is likely due to the fact that some patients possess anti- $\beta 2$ GPI antibodies that interact with other domains (DII-V) and is entirely consistent with results from previous experiments using DI expressed in insect cells [29].

This methodology demonstrates a relatively simple, inexpensive, reproducible and semi-automated bench top method for the expression, folding and purification of human DI up to a $0.1-0.15 \mathrm{~g}$ scale. This system opens the possibility for the development of DI as a potential therapeutic agent for APS.

\section{Competing interests}

TM is funded by an MRC CASE studentship and works in partnership with PolyTherics (an ABZENA company). EL and RT were employed by PolyTherics (an ABZENA company) during the period of work. TM, CP, YI, AR and IG are listed as inventors on a patent for PolyTherics.

\section{Authors' contributions}

TM: carried out expression work, purifications, activity testing and all optimisation therein involved, also took the lead in writing and drafting the manuscript. CP: devised the inhibition ELISA and optimised it in its initial forms. EL: helped with initial small scale studies and drafting the manuscript. RT: helped with larger scale expression and automation. AGG: Construction of the expression vector used in this study and tutelage to TM during early small scale studies. IG: contributed to study design and critically revised the manuscript. Yl: devised the DI synthetic gene, periplasmic expression vector and also provided supervision. AR: supplied supervision to TM and aided in drafting the manuscript.

\section{Acknowledgements}

AGG was founded by MRC File Reference U117574559. YI, IG and AR are supported by the National Institute for Health Research University College London Hospitals Biomedical Research Centre and $\mathrm{Yl}$ is supported by Arthritis Research UK Grant 20164. CP is supported by Arthritis Research UK Programme Grant 19423

\section{Author details}

${ }^{1}$ Centre for Rheumatology, Division of Medicine, University College London, Rayne Institute, 5 University Street, London WC1E 6JF, UK. PolyTherics, Babraham Research Campus, Babraham, CB22 3AT Cambridge, UK. ${ }^{3}$ Structural Biology, Medical Research Council National Institute for Medical Research, London, UK. ${ }^{4}$ Arthritis Research UK Centre for Adolescent Rheumatology, University College London, London, UK.

Received: 28 April 2015 Accepted: 3 November 2015

Published online: 14 November 2015

\section{References}

1. Kelly SJ, Delnomdedieu M, Oliverio MI, Williams LD, Saifer MG, Sherman MR, et al. Diabetes insipidus in uricase-deficient mice: a model for evaluating therapy with poly (ethylene glycol)-modified uricase. J Am Soc Nephrol. 2001;12(5):1001-9.

2. Sundy JS, Becker MA, Baraf HS, Barkhuizen A, Moreland LW, Huang W, et al. Reduction of plasma urate levels following treatment with multiple doses of pegloticase (polyethylene glycol-conjugated uricase) in patients with treatment-failure gout: results of a phase II randomized study. Arthritis Rheum. 2008;58(9):2882-91.

3. Sundy JS, Ganson NJ, Kelly SJ, Scarlett EL, Rehrig CD, Huang W, et al. Pharmacokinetics and pharmacodynamics of intravenous PEGylated recombinant mammalian urate oxidase in patients with refractory gout. Arthritis Rheum. 2007;56(3):1021-8.

4. Ganson NJ, Kelly SJ, Scarlett E, Sundy JS, Hershfield MS. Control of hyperuricemia in subjects with refractory gout, and induction of antibody against poly (ethylene glycol) (PEG), in a phase I trial of subcutaneous PEGylated urate oxidase. Arthritis Res Ther. 2006;8(1):R12.

5. Sundy JS, Baraf HS, Yood RA, Edwards NL, Gutierrez-Urena SR, Treadwell EL, et al. Efficacy and tolerability of pegloticase for the treatment of chronic gout in patients refractory to conventional treatment: two randomized controlled trials. JAMA. 2011;306(7):711-20.

6. Sherman MR, Saifer MG, Perez-Ruiz F. PEG-uricase in the management of treatment-resistant gout and hyperuricemia. Adv Drug Deliv Rev. 2008:60(1):59-68.

7. Lipton JH, Khoroshko N, Golenkov A, Abdulkadyrov K, Nair K, Raghunadharao $D$, et al. Phase II, randomized, multicenter, comparative study of peginterferonalpha-2a (40 kD) (Pegasys) versus interferon alpha-2a (Roferon-A) in patients with treatment-naive, chronic-phase chronic myelogenous leukemia. Leuk Lymphoma. 2007;48(3):497-505.

8. Fried MW, Shiffman ML, Reddy KR, Smith C, Marinos G, Goncales Jr FL, et al. Peginterferon alfa-2a plus ribavirin for chronic hepatitis $C$ virus infection. N Engl J Med. 2002;347(13):975-82.

9. Fleischmann R, Vencovsky J, van Vollenhoven RF, Borenstein D, Box J, Coteur $G$, et al. Efficacy and safety of certolizumab pegol monotherapy every 4 weeks in patients with rheumatoid arthritis failing previous disease-modifying antirheumatic therapy: the FAST4WARD study. Ann Rheum Dis. 2009:68(6):805-11.

10. Horton S, Walsh C, Emery P. Certolizumab pegol for the treatment of rheumatoid arthritis. Expert Opin Biol Ther. 2012;12(2):235-49.

11. Keystone E, Heijde D, Mason Jr D, Landewe R, Vollenhoven RV, Combe B, et al. Certolizumab pegol plus methotrexate is significantly more effective than placebo plus methotrexate in active rheumatoid arthritis: findings of a fifty-two-week, phase III, multicenter, randomized, double-blind, placebocontrolled, parallel-group study. Arthritis Rheum. 2008;58(11):3319-29.

12. Voulgaridou GP, Mantso T, Chlichlia K, Panayiotidis MI, Pappa A. Efficient E. coli expression strategies for production of soluble human crystallin ALDH3A1. PLoS One. 2013;8(2):e56582.

13. Johnson IS. Human insulin from recombinant DNA technology. Science. 1983;219(4585):632-7.

14. Chevaliez S, Pawlotsky JM. Interferon-based therapy of hepatitis C. Adv Drug Deliv Rev. 2007;59(12):1222-41.

15. Scopes RK. Protein purification : principles and practice. 2nd ed. New York: Springer; 1987. 
16. Smales CM, James DC. Therapeutic proteins : methods and protocols. Totowa, N.J.: Humana Press; 2005.

17. Lobstein J, Emrich CA, Jeans C, Faulkner M, Riggs P, Berkmen M. SHuffle, a novel Escherichia coli protein expression strain capable of correctly folding disulfide bonded proteins in its cytoplasm. Microb Cell Factories. 2012;11.

18. Bessette PH, Aslund F, Beckwith J, Georgiou G. Efficient folding of proteins with multiple disulfide bonds in the Escherichia coli cytoplasm. Proc Natl Acad Sci U S A. 1999:96(24):13703-8.

19. Jaffe SR, Strutton B, Levarski Z, Pandhal J, Wright PC. Escherichia coli as a glycoprotein production host: recent developments and challenges. Curr Opin Biotechnol. 2014;30:205-10.

20. De Jesus M, Wurm FM. Manufacturing recombinant proteins in kg-ton quantities using animal cells in bioreactors. Eur J Pharm Biopharm. 2011;78(2):184-8.

21. Wurm FM. Production of recombinant protein therapeutics in cultivated mammalian cells. Nat Biotechnol. 2004;22(11):1393-8.

22. Macauley-Patrick S, Fazenda ML, McNeil B, Harvey LM. Heterologous protein production using the Pichia pastoris expression system. Yeast. 2005;22(4):249-70.

23. Ioannou Y, Romay-Penabad Z, Pericleous C, Giles I, Papalardo E, Vargas G, et al. In vivo inhibition of antiphospholipid antibody-induced pathogenicity utilizing the antigenic target peptide domain I of beta2-glycoprotein I: proof of concept. J Thromb Haemost. 2009;7(5):833-42.

24. Lambrianides A, Carroll CJ, Pierangeli SS, Pericleous C, Branch W, Rice J, et al. Effects of polyclonal lgG derived from patients with different clinical types of the antiphospholipid syndrome on monocyte signaling pathways. J Immunol. 2010;184(12):6622-8.

25. Ioannou Y, Pericleous C, Giles I, Latchman DS, Isenberg DA, Rahman A Binding of antiphospholipid antibodies to discontinuous epitopes on domain I of human beta (2)-glycoprotein I: mutation studies including residues R39 to R43. Arthritis Rheum. 2007:56(1):280-90

26. Alessandri C, Conti F, Pendolino M, Mancini R, Valesini G. New autoantigens in the antiphospholipid syndrome. Autoimmun Rev. 2011;10(10):609-16.

27. Galli M, Comfurius $P$, Maassen $C$, Hemker HC, de Baets MH, van BredaVriesman PJ, et al. Anticardiolipin antibodies (ACA) directed not to cardiolipin but to a plasma protein cofactor. Lancet. 1990;335(8705):1544-7.

28. McNeil HP, Simpson RJ, Chesterman CN, Krilis SA. Anti-phospholipid antibodies are directed against a complex antigen that includes a lipidbinding inhibitor of coagulation: beta 2-glycoprotein I (apolipoprotein $\mathrm{H}$ ). Proc Natl Acad Sci U S A. 1990;87(11):4120-4.

29. Iverson GM, Victoria EJ, Marquis DM. Anti-beta2 glycoprotein I (beta2GPI) autoantibodies recognize an epitope on the first domain of beta2GPI. Proc Natl Acad Sci U S A. 1998;95(26):15542-6.

30. Pierangeli SS, Espinola RG, Liu X, Harris EN. Thrombogenic effects of antiphospholipid antibodies are mediated by intercellular cell adhesion molecule-1, vascular cell adhesion molecule-1, and P-selectin. Circ Res. 2001;88(2):245-50.

31. Pierangeli SS, Liu SW, Anderson G, Barker JH, Harris EN. Thrombogenic properties of murine anti-cardiolipin antibodies induced by beta 2 glycoprotein 1 and human immunoglobulin $\mathrm{G}$ antiphospholipid antibodies. Circulation. 1996;94(7):1746-51.

32. Khamashta MA, Cuadrado MJ, Mujic F, Taub NA, Hunt BJ, Hughes GR. The management of thrombosis in the antiphospholipid-antibody syndrome. N Engl J Med. 1995;332(15):993-7.

33. Reddel SW, Wang YX, Sheng YH, Krilis SA. Epitope studies with anti-beta 2-glycoprotein I antibodies from autoantibody and immunized sources. J Autoimmun. 2000;15(2):91-6.

34. Ioannou Y, Rahman A. Domain I of beta2-glycoprotein I: its role as an epitope and the potential to be developed as a specific target for the treatment of the antiphospholipid syndrome. Lupus. 2010;19(4):400-5.

35. Bertolaccini ML, Amengual O, Andreoli L, Atsumi T, Chighizola CB, Forastiero R, et al. 14th International Congress on Antiphospholipid Antibodies Task Force. Report on antiphospholipid syndrome laboratory diagnostics and trends. Autoimmun Rev. 2014;13(9):917-30.

36. loannou Y, Giles I, Lambrianides A, Richardson C, Pearl LH, Latchman DS, et al. A novel expression system of domain I of human beta2 glycoprotein I in Escherichia coli. BMC Biotechnol. 2006;6:8.

37. Pericleous C, Miles J, Esposito D, Garza-Garcia A, Driscoll PC, Lambrianides $A$, et al. Evaluating the conformation of recombinant domain I of beta (2)-glycoprotein I and its interaction with human monoclonal antibodies. Mol Immunol. 2011;49(1-2):56-63.

38. Fink AL. Protein aggregation: folding aggregates, inclusion bodies and amyloid. Fold Des. 1998:3(1):R9-23.

39. Studier FW. Protein production by auto-induction in high density shaking cultures. Protein Expr Purif. 2005;41(1):207-34.

\section{Submit your next manuscript to BioMed Central and take full advantage of:}

- Convenient online submission

- Thorough peer review

- No space constraints or color figure charges

- Immediate publication on acceptance

- Inclusion in PubMed, CAS, Scopus and Google Scholar

- Research which is freely available for redistribution 